\title{
Orman's Internet Addiction Survey: a Preliminary Psychometric Study in an Universitary Andalusian Sample*
}

\section{Encuesta sobre adicción al internet de Orman: Un estudio psicométrico preliminar en una muestra universitaria de Andalucía}

Recibido: 12 de abril de 2013 | Revisado: 2 de marzo de 2014 | Aceptado: 20 de febrero de 2015

\author{
ANTONIO MATAS ** \\ Universidad de Málaga, España
}

doi:10.11144/Javeriana.upsy14-3.oias

Para citar este artículo: Matas, A. (2015). Orman's Internet Addiction Survey: A preliminary psychometric study in an universitary Andalusian sample. Universitas Psychologica, 14(3), 1107-1116. http:// dx.doi.org/10.11144/Javeriana.upsy14-3.oias

* Artículo de investigación

** Correo electrónico: amatas@uma.es

\begin{abstract}
A B S T R A C T
In recent decades several instruments have been developed to assess the behaviour of being continuously connected to Internet shown by some Internet users. The Internet Addiction Survey by Mc. Orman is one of them. Its psychometric properties are analysed in this article, using an incidental sample of university students. The results showed a satisfactory level of reliability and a one-dimensional underlying structure, with high correlation values with other instruments used for the same purpose. Its use is recommended in the study of Internet addiction.

Keywords

addictive behaviour; internet; test reliability; test validity; statistical analysis

RESUMEN

En las últimas décadas se han desarrollado diversos instrumentos para medir el comportamiento de estar continuamente conectado a Internet, presentado por algunos usuarios. En este artículo se analizan sus características psicométricas a partir de una muestra incidental de estudiantes universitarios. Los resultados muestran una fiabilidad satisfactoria y una estructura latente unidimensional, presentando valores de correlación altos con otros instrumentos utilizados con el mismo fin. Se sugiere su utilización para el estudio de la Adicción a Internet.

Palabras clave

comportamiento adictivo; internet; fiabilidad; validez; análisis estadístico
\end{abstract}


Over the last decade, Internet has become widespread in work, academic and leisure environments, thanks to the technical and commercial infrastructure that has enabled easy access. At the same time, some users have appeared, and appear, to show a disproportionate tendency to be connected at all times (Davis, Flett, \& Besser, 2002; Echeburúa, 1999). This phenomenon has been classed as a type of addiction, insofar as it can be due to a loss of control by the person in question (Echeburúa \& De Corral, 2010).

Internet addiction is not considered to be a pathology by benchmark institutions such as the American Psychiatric Association or the World Health Organisation. However, several authors have expressed their convictions that it will be classed as mental disorder in the very near future (Block, 2008; Hollander \& Allen, 2006).

In any case, Internet addiction could be defined as the use of the services offered by the Net to the extent that the person, or their environment, experiences dysfunctional consequences on a social, psychological or physical level. In Internet addiction, the degree of interference with the person's daily life takes precedence over connection time (Davis, 2001; Estallo, 2001).

There are different types of abusive use of Internet and situations of interactions with other pathologies (Mittal, Tessner, \& Walker, 2007; SánchezCarbonell, Berauny, Castellana, \& Oberst, 2008). The data on the prevalence of Internet addiction depends on the studies examined. In English-speaking samples, addiction of between $4 \%$ and $18 \%$ has been found, whereas in Spanish samples, the values are somewhat lower, with percentages varying from 3\% to 6\% (Berauny, Chamarro, Graner, \& Carbonell, 2009; De Gracia, Vigo, Fernández, \& Marcó, 2002b).

Several instruments have been developed to measure this phenomenon. Among them is Young's test (1998). This is a 20-item scale developed from eight diagnostic criteria (sleep deprivation as a result of being online, failure to attend important activities, receiving complaints from someone close, constantly thinking of Internet, unsuccessfully attempting to reduce connection time, lying about connection time, socially isolating oneself, and feeling unusually happy or excited when online). The questionnaire has been validated by researchers like Widyanto and McMurran (2004). Although this questionnaire is used frequently, it has been put into question due to its psychometric quality, its capacity to distinguish between addicts and non-addicts, and for having been constructed from the criteria of other addictions (Huang, Qian, Zhong, \& Tao, 2007). Another instrument is the Online Cognitive Scale (OCS) by Davis et al. (2002), which is made up of 36 items. For these authors, the addiction comes about when a person moves away from their real social environment and replaces it with an online environment. Other instruments are the PIU (Pathological Internet Use) Scale by Morahan-Martin and Schumacher (2000) and the PRI (Problems Related to Internet use) Scale by De Gracia, Vigo, Fernández, and Marcó (2002a) among others.

Another, less frequently used instrument is the Internet Addiction Survey by M.C. Orman (1996). Initially, it was made to measure stress, but it shows relation with internet addiction and proof of being related with Young's test have been collected (Echeburúa \& De Corral, 2010). However, studies about its psychometric properties have not been found in consulted literature.

Taking all this into account, the main aim of this study, is to analyse the psychometric properties of M.C. Orman's survey of 1996, including regard evidence about its internal consistency and external validity. Also, it is aimed to analyse if there is relationship between results of Orman's survey with self-perception of Internet use's interference in daily life, and to analyse if there is differences in the result of Orman's survey for the sociodemographic segments of the sample (sex, age, residence, etc.)

\section{Method}

\section{Design and Sample}

For the purposes of this study, a "survey design" was carried out on a non-probability sample of university students. The sample of participants 
was carried out from a population of 27092 university students from the career of Education, from eight universities in Andalucia (southern Spain region) (data from Andalucian Institute of Statistc in 2011). In the population, $71.5 \%$ were women, with median $(\mathrm{Md})$ of 22 years of age (Q1 $=20 ; \mathrm{Q} 3=25$ ).

The sample was selected by an incidentally process. It included 324 participants, all Education students, of ages between 17 and 55 years (Q1 = 20; $\mathrm{Q} 3=23 ; \mathrm{Md}=21$ ) where, $77.37 \%$ were women. Furthermore, the participants shared their habitual home with 3, 4 or 5 people in $69.72 \%$ of cases, while $26 \%$ lived with fewer than 3 people and $4.20 \%$ shared their residence with more than 5 people. With regard to the technological resources used by the participants, the use of laptops (77.3\%) and desktop PCs (46.74\%) predominated. Out of all the students who were asked, 35.29\% of the participants claimed that they also usually used smartphones to access Internet, while 4.6\% of those surveyed claimed to use tablets (including the iPad model).

\section{Instruments}

An ad-hoc instrument was made. It was structured in four blocks of items (Appendix I):

- General socio-demographic information, including an item on which computer resources the participants habitually used.

- The second set of questions was made up of items from the Internet Addiction Survey (Orman, 1996) and items from the Internet Addiction Test (Young, 1998). This test was used to obtain external validity proofs.

- The third set of questions aimed to gather information about internet consumption.

- Lastly, two questions were included that had a dichotomous response, the purpose of which was to find out whether the participants perceived that internet use had any degree of interference in their life, or whether they had been warned by people around them of a disproportionate use of technology in general.
Orman's Internet Addiction Survey (1996) is a test made up of 9 items with Yes or No answers. Following the author's original recommendations, the level of Internet addiction would be determined by adding the number of Yes answers in the set of nine items that make up the test. A number above 7 would indicate problems of dependence; 3 points or below would show an absolute absence of problems; while an intermediate score would indicate that the person is in the risk zone. An adaptation of this instrument was used in this research study, which included two modifications: the Spanish version used by Echeburúa and De Corral (2010) was applied; and a 5-point response scale was included. In this way, the items' sensitivity to minor estimation differences between participants was increased, while also enabling the response format to be in line with Young's Internet Addiction Test (1998).

The interpretation was scaled in such a way that a score over 35 indicated problems controlling Internet use, whereas a score below 15 indicated an absence of problems. Intermediate scores were associated with a risk situation.

The Internet Addiction Test (IAT) by Young (1998 is made up of 20 items, the responses to which follow a five-point Likert-type scale. In this instrument, the author suggests that a score of 20 to 39 points would indicate that the person has full control over internet use. A score between 40 and 69 points would indicate possible problems with Internet use, where the person would be considered to be in a situation of risk. Lastly, a score over 70 would indicate that the person has definite problems with Internet use.

\section{Process}

The information was gathered during the months of October and November 2011 in the same classrooms in which the students habitually attended class. Participation was voluntary, guaranteeing data custody and anonymity. The instruments were administered by teachers after an informative session about how do it. 
Analysis

Different statistical techniques were applied, including a descriptive analysis of the variables. An exploratory factor analysis of the items was applied. It is recommended to get a crossed validation of all analysed items and with this to develop a first exploration of the internal structure (Carretero \& Pérez, 2007; Floyd \& Widaman, 1995). To ease the interpretation of outcomes from the analysis, the Principal Component Analysis (PCA) is recommended (Cortina, 1993) adding an orthogonal rotation VARIMAX (García-Jiménez, 2000). The ordinal variables were coded, then quality and numeric code are linked, and a PCA was developed (Cea, 2011). Subsequently, Cronbach alpha coefficients for each factor and for total scales were calculated.

To get conclusions about the external validity several analysis of relation between the outcomes of the scales, the item of self-perceived use of Internet and the item of self-perceived addiction were applied. Finally, ANOVA's were applied to analyse if there were differences between sociodemographics segments in the scales. The SPSS version 19 programme for Mac was used for the analysis.

\section{Results}

\section{Internet Addiction Survey (IAS)}

To analyse the underlying structure of the data, a Principal Component Analysis (PCA) was applied, which obtained a Kaiser-Mayer-Olkin adequacy measure of 0.895, while the Bartlett's sphericity test produced a Chi-square of $865.837(p<0.0001)$. The PCA suggested the existence of a single factor explaining $44.754 \%$ of the variance (eigenvalue $=$ 4.028). The weights of the items in the component are listed in Table 1. Cronbach's alpha for the internal consistency was 0.842 , verifying that the consistency value did not improve when any item was removed.

\section{Internet Addiction Test (IAT)}

The internal data structure was explored using the PCA. The Kaiser-Mayer-Olkin test obtained a result of 0.915 , with a chi-square of 2501.94 ( $p 0<$ 0.0001 ) in Bartlett's test. The PCA analysis offered a 4-component solution that explained $57.119 \%$ of the variance (see aigenvalues in Table 2). These components were rotated towards the maximum orthogonal position in 5 iterations by means of the VARIMAX method (Table 2).

\section{TABLE 1}

Matrix of Components for IAS Survey

\begin{tabular}{clc}
\hline Variable & \multicolumn{1}{c}{ Item } & Component 1 \\
\hline V19 & Do you have problems controlling your impulse to connect to Internet? & 0.788 \\
\hline V16 & Do you find it hard to keep away from Internet for several days at a time? & 0.773 \\
\hline V14 & Do you think you will feel bad if you spend less time on Internet? & 0.729 \\
\hline V18 & Are there any online services or contents that you find hard to resist? & 0.667 \\
\hline V21 & Do you get much of your pleasure from being connected to the Internet? & 0.662 \\
\hline V13 & Do you spend more time online than you think you should for purposes other than work? & 0.637 \\
\hline V17 & Do your relationships suffer as a result of being online? & 0.608 \\
\hline V15 & Have members of your family complained about the amount of time you spend on Internet? & 0.593 \\
\hline V20 & Have you tried, unsuccessfully, to curtail your use of Internet? & 0.518 \\
\hline & Eigenvalue & 4.028 \\
\hline
\end{tabular}

Extraction method: Main components

Source: own work 
TABLE 2

Matrix of Components for IAT Test

\begin{tabular}{|c|c|c|c|c|c|}
\hline Variable & Item & Comp. 1 & Comp. 2 & Comp. 3 & Comp. 4 \\
\hline V23 & $\begin{array}{l}\text { How often do you neglect the things you need to do around the } \\
\text { house to spend more time online? }\end{array}$ & 0.729 & & & \\
\hline V26 & $\begin{array}{l}\text { How often do people in your life complain about the amount of } \\
\text { time you spend on Internet? }\end{array}$ & 0.707 & & & \\
\hline V37 & $\begin{array}{l}\text { How often do you say to yourself "just a few minutes more" when } \\
\text { you're online? }\end{array}$ & 0.688 & 0.331 & & \\
\hline V22 & $\begin{array}{l}\text { How often do you spend more time online than you had } \\
\text { intended? }\end{array}$ & 0.661 & & & \\
\hline V27 & $\begin{array}{l}\text { How often do your studies or work suffer because of the amount } \\
\text { of time you spend online? }\end{array}$ & 0.65 & & 0.407 & \\
\hline V35 & How often do you lose sleep because you are online? & 0.603 & & & \\
\hline V38 & $\begin{array}{l}\text { How often have you attempted to reduce the amount of time you } \\
\text { spend online, and failed? }\end{array}$ & 0.591 & 0.327 & & \\
\hline V29 & $\begin{array}{l}\text { How often does your work or academic performance or } \\
\text { productivity suffer because of your Internet use? }\end{array}$ & 0.547 & & 0.355 & 0.33 \\
\hline V33 & $\begin{array}{l}\text { How often do you feel that life without Internet would be boring, } \\
\text { empty and joyless? }\end{array}$ & & 0.744 & & \\
\hline V36 & $\begin{array}{l}\text { How often do you think about Internet when offline, or fantasise } \\
\text { about being online? }\end{array}$ & & 0.714 & & \\
\hline V32 & $\begin{array}{l}\text { How often do you find yourself thinking about when you will go } \\
\text { online again? }\end{array}$ & & 0.685 & 0.316 & \\
\hline V31 & $\begin{array}{l}\text { How often do you block out disturbing thoughts about your life } \\
\text { with relaxing thoughts of the Internet? }\end{array}$ & & 0.641 & 0.307 & \\
\hline V41 & $\begin{array}{l}\text { How often do you feel depressed, moody or nervous when you } \\
\text { are offline, then these feelings go away when you are back online? }\end{array}$ & & 0.6 & 0.416 & \\
\hline V25 & $\begin{array}{l}\text { How often do you form new relationships with other people using } \\
\text { Internet? }\end{array}$ & & 0.478 & & \\
\hline V40 & $\begin{array}{l}\text { How often do you choose to spend more time online than going } \\
\text { out with friends? }\end{array}$ & & & 0.803 & \\
\hline V24 & $\begin{array}{l}\text { How often do you prefer the excitement of being online to } \\
\text { intimacy with your partner, family or friends? }\end{array}$ & & & 0.704 & \\
\hline V34 & $\begin{array}{l}\text { How often do you snap, shout or get annoyed when someone } \\
\text { bothers you while you are online? }\end{array}$ & 0.401 & 0.311 & 0.518 & \\
\hline V39 & $\begin{array}{l}\text { How often do you try to hide the amount of time you have been } \\
\text { online? }\end{array}$ & 0.398 & 0.414 & 0.496 & \\
\hline V30 & $\begin{array}{l}\text { How often do you become defensive or secretive about your } \\
\text { online activities? }\end{array}$ & & 0.345 & 0.426 & \\
\hline V28 & How often do you check your e-mail before doing anything else? & & & & 0.901 \\
\hline & Internal consistency (Cronbach's alpha) & 0.858 & 0.81 & 0.777 & - \\
\hline & Eigenvalue & 7.68 & 1.495 & 1.194 & 1.055 \\
\hline
\end{tabular}

Extraction method: Main components.

Rotation method: VARIMAX with Kaiser normalisation.

The weights below 0.3 have been removed for a better reading.

Source: own work

The first component focused on time management in Internet connection (V23, V26, V37, etc.) with an explained variance of $38.4 \%$ of the total. The second component, with an explana- tory capacity of $7.47 \%$ of the variance, related to a prominence of thoughts about being connected to Internet (V36, V32, etc.). The third component explained $5.9 \%$ of the variance, associated with 
interference in social relationships (V40, V39, etc.). Lastly, the fourth component explained $5.27 \%$ of the variance, concentrated mainly on item 28 . The internal consistency value using Cronbach's alpha was 0.902 . This value rose to 0.911 when item 28 (V28) was removed.

\section{Internet Consumption}

The score for each participant was calculated by adding the scores for each item in each test. With regard to the level of Internet addiction using Orman's Internet Addiction Survey, the sample average was 19.48 points $(S D=6.383 ;$ S.E. $=0.353)$ out of a maximum score of 45 points and a minimum of 9 points. When the interpretation indications for this test were applied, the result showed that $5.6 \%$ of those taking part in the survey had control problems, while $43.2 \%$ were in a situation of risk. A figure of $51.2 \%$ had no problem at all.

Regarding Young's Internet Addiction Test, the questionnaire revealed an average of direct scores of 37.27 points $(S D=10.41$; S.E. $=0.578)$ out of the available maximum of 100 points. Interpreting the sample scores following the author's recommendations, $1.5 \%$ showed addiction problems, while $34.16 \%$ were in an intermediate situation and $63.9 \%$ did not show any sign of problems.

The participants' direct scores were calculated and interpreted for the four components arising from the PCA. To do so, the interpretations were scaled according to the maximum possible score for each component. With regard to time management, $44.17 \%$ showed no control problems, although $51.54 \%$ were found to be in a situation of risk. For the second component (prominence of thoughts related to Internet), the majority of participants (69.97\%) showed no associated problems. In the third component, related to interference in one's social life, the same profile as before was found (see Table 3).

As regards connection time, most of the participants $(52.5 \%)$ declared that they connected to Internet for under 2 hours a day, apart from the hours spent online for their work or studies (V42), followed by $37.8 \%$ that claimed to connect between 2 and 5 hours a day. Only 7.2\% stated that they go online for more than 5 hours a day. The main places where the participants connected were their habitual residence (97.2\%) along with the university faculty (36.7\%). Other available places, such as public spaces, Internet cafés or similar, recorded percentages below $7 \%$.

Regarding the expense incurred as a result of connecting to Internet, the participants' family (parents or tutors) covered the costs in $76.9 \%$ of the cases, although $5 \%$ did say that they were jointly responsible for this payment.

\section{Participants' Self-Perceived Use of Internet}

According to the results, $28.25 \%$ of the participants stated that their Internet use interfered in their lives (V45). Along with this information, item V46 endeavoured to find any observations from the participants' social environment regarding technology in general. In this item, $15 \%$ of those surveyed reported having received some type of warning to this effect.

Relationship between Scores in IAS and IAT

The direct scores of the IAS survey and IAT test showed a Spearman correlation $(\mathrm{R})$ of $0.742(p$

TABLE 3

Response Percentages in the IAT Test Components

\begin{tabular}{llccc}
\hline Component & Description & No problems (\%) & Risk (\%) & Addiction (\%) \\
\hline Comp. 1 & Time management & 44.6 & 51.1 & 4.3 \\
\hline Comp. 2 & Prominence of thoughts about Internet & 70.6 & 27.8 & 1.6 \\
\hline Comp. 3 & Interference in social life & 85 & 14.7 & 0.3 \\
\hline Comp. 4 & E-mail & 6.5 & 43.2 & 50.3 \\
\hline
\end{tabular}

Source: own work 
$<0.0001)$. The relationships between the scores obtained by the participants in the IAS and the scores obtained in each of the four components of the IAT were also compared. All the correlations were significant, except in the case of the fourth component (item V28) (Component $1=0.713$; Component $2=0.604$; Component $3=0.574$; all of them at $p<0.0001$ ).

\section{Relationship between Scores in IAS, IAT, and Self-Perceived Use}

Likewise, an analysis was made of the relationship between the IAT test, the IAT components and the IAS survey with the item on self-perception, and also with the item on warnings from one's environment (V45 and V46, respectively). The results of the chi-square test and the Contingency Coefficient reveal significant relationships with all scales except the fourth component of the IAT test (Table 4).

\section{Differences between Socio-Demographic} Segments in the Sample

An analysis of variance (ANOVA) was also applied to the scores obtained in the IAT and IAS according to age. The results revealed significant differences for both tests. In the case of the IAS survey, the results showed an $F$ value of 2.373 ( $d f$ $=26 ; p<0.0001)$. The Pearson product-moment correlation between both variables was $-0.12(p<$ 0.0001), which supports the significant differences in such a way that older individuals manifested a lesser degree of Internet addiction according to the IAS survey. The differences in the IAT test were significant with an $F$ value of $1.727(d f=26 ; p=$ 0.017). The tendency of the differences was also verified with the Pearson product-moment correlation $(R=-0.16 ; p<0.0001)$, manifesting the same inverse tendency as the previous test.

With regard to connection time, a greater connection time was found to entail a higher score, both in the IAS test $(F=32.03 ; p<0.0001)$ with a product-moment correlation of $0.47(p<0.0001)$, and in the IAT test $(F=22.36 ; p<0.0001)$, which showed a somewhat lower, yet equally significant, correlation $(R=0.42 ; p<0.0001)$. No other significant differences were found with the rest of the socio-demographic variables.

\section{Discussion and Conclusions}

The Internet Addiction Survey has convergenced with the IAT, which has been highlighted in other research studies (Echeburúa \& De Corral, 2010). In addition, compared with other instruments such as the IAT (Young, 1998), the PIU (MorahanMartin \& Schumacher, 2000) or the OCS (Davis et al., 2002), among others, the IAS presents a onedimensional structure. In any case, the problem of analysing the validity of these tests is a critical question, as has been made evident in previous studies (Huang et al., 2007).

The study reveals interesting questions. With regard to the structure of the IAT test, the internal consistency results are similar to the values obtained by Widyanto and McMurran (2004). In this structure, the role of the component on social relationships is clear. To this effect, it is important to consider that Internet may not necessarily be limiting a person's social dimension, but rather it

TABLE 4

Correlation IAS, IAT and IAT Components

\begin{tabular}{ccccccccccccc}
\hline & IAT & & Comp. 1 & \multicolumn{3}{c}{ Comp. 2 } & \multicolumn{2}{c}{ Comp. 3 } & \multicolumn{3}{c}{ Comp. 4 } & \multicolumn{3}{c}{ IAS } \\
\hline \multicolumn{2}{c}{$\chi^{2}$} & CC & $\chi^{2}$ & CC & $\chi^{2}$ & CC & $\chi^{2}$ & CC & $\chi^{2}$ & CC & $\chi^{2}$ & CC \\
\hline V45 & $55.661 *$ & $0.385^{*}$ & $65.446^{*}$ & $0.413^{*}$ & $35.258^{*}$ & $0.317^{*}$ & $20.072^{*}$ & $0.25^{*}$ & 1.242 & 0.062 & $46.202^{*}$ & $0.356^{*}$ \\
\hline V46 & $25.343^{*}$ & $0.271^{*}$ & $36.840^{*}$ & $0.322^{*}$ & $24.871^{*}$ & $0.271^{*}$ & $19.749^{*}$ & $0.248^{*}$ & 1.093 & 0.058 & $38.864^{*}$ & $0.33^{*}$ \\
\hline
\end{tabular}

$* p<0.0001$.

Source: own work 
may be modifying the means with which social interaction develops. This, therefore, exceeds the proposals made by Davis et al. (2002), who set the physical social environment against the Internet environment, and used it as a criterion to identify situations of social risk.

The result of item V42 about Internet connection time is in keeping with recent research, such as the study carried out by Muñoz-Rivas, Fernández, and Gámez-Guadix (2010). It seems reasonable that future studies may confirm that the habitual connection time is in the region of three hours per day, and that this time is used for personal matters, away from professional or educational purposes.

As regards this study's main objective, the IAS survey is an instrument that:

- has shown similar psychometric properties to more frequently used instruments,

- has presented a one-dimensional structure, and is made up of fewer items than other, similar, instruments.

The high correlation observed between the IAS survey and the IAT test suggests the concurrent external validity of the instruments. Nevertheless, the relationships between the IAS survey and the IAT components are not similar. These relationships are higher for time management and for thoughts about Internet (components 1 and 2, respectively).

Furthermore, the ANOVA's analysis confirmed the difference between hours of connection and addiction in both instruments, as well as differences in age that have been found in previous studies (Davis et al., 2002; Muñoz-Rivas et al., 2010; Carbonell, Castellana, \& Oberst, 2010).

To conclude, we would like to offer two final elements of reflection:

- Firstly, the moderately high relationship found between the direct question that the participants were asked (V45) and the scores in the IAT and the IAS, makes one wonder whether an instrument based on a few direct questions is enough to ensure a true analysis of the situation.

- Secondly, variable 28 (on checking e-mail) in the IAT test has shown a different re- sults profile from all the other items. We must ask ourselves whether, during work or study time, when people should be focusing on performing a particular task, repeatedly checking e-mail is the only admissible task that is capable of offering the positive reinforcement that momentarily satisfies the desire to go online. If this hypothesis were to be verified in subsequent studies, this indicator could be included in the instruments, making it easier to identify risk situations in study and work places.

Despite the limitations inherent in a study with non-randomised samples, the results offer an orientative and pragmatic view of the psychometric properties of Orman's scale. However, further studies with probability samples will need to be carried out in order to confirm these properties.

\section{References}

Berauny, M., Chamarro, A., Graner, C., \& Carbonell, X. (2009). Validación de dos escalas breves para evaluar la adicción a Internet y el abuso del móvil. Psicothema, 21(3), 480-485.

Block, J. J. (2008). Issues for DSM-V: Internet addiction. American Journal of Psychiatry, 165(3), 306-307.

Carbonell, X., Castellana, M., \& Oberst, U. (2010, January). Sobre la adicción a Internet y al teléfono móvil. Revista de Educación Social. Retrieved from http://www.eduso.net/res/?b=14\&c=129\&n=371

Carretero, H., \& Pérez, C. (2007). Standards for the development and review of instrumental studies: Considerations about test selection in psychological research. International Journal of Clinical and Health Psychology, 7(3), 863-882.

Cea, M. A. (2011). Análisis multivariable: teoría y práctica en la investigación social. Madrid: Síntesis.

Cortina, J. M. (1993). What is coefficient alpha? An examination of theory and applications. Journal of Applied Psychology, 78(1), 98-104.

Davis, R. A. (2001). A cognitive-behavioral model of pathological Internet use. Computers in Human Behavior, 17(2), 187-195. 
Davis, R. A., Flett, G. L., \& Besser, A. (2002). Validation of a new scale for measuring problematic Internet use: Implications for pre-employment screening. CyberPsychology $\mathcal{E}$ Behavior, 5(4), 331-345.

De Gracia, M., Vigo, M., Fernández, M. J., \& Marcó, M. (2002a). Problemas conductuales relacionadas con el uso de Internet: un estudio exploratorio. Anales de Psicología, 18(2), 273-292.

De Gracia, M., Vigo, M., Fernández, M. J., \& Marcó, M. (2002b). Características conductuales del uso excesivo de Internet. Revista de Psiquiatría de la Facultad de Medicina de Barcelona, 29(4), 219-230.

Echeburúa, E. (1999). iAdicciones sin drogas? Bilbao: Desclée de Brouwer.

Echeburúa, E., \& De Corral, P. (2010). Adicción a las nuevas tecnologías y a las redes sociales en jóvenes: un nuevo reto. Adicciones, 22(2), 91-96.

Estallo, J. A. (2001). Usos y abusos de internet. Anuario de Psicología, 32, 95-108.

Floyd, F. J., \& Widaman, K. F. (1995). Factor analysis in the development and refinement of clinical assessment instruments. Psychological Assessment, 7(3), 286-299.

García-Jiménez, E. (2000). Análisis sectorial. En A. Matas (Comp.), Análisis de datos II (pp. 99-120). Sevilla: Kronos.

Hollander, E., \& Allen, A. (2006). Is compulsive buying a real disorder, and is it really compulsive. The American Journal of Psychiatry, 163(10), 1670-1672.

Huang, Z., Wang, M., Qian, M., Zhong, J., \& Tao, R. (2007). Chinese Internet Addiction Inventory: Developing a measure of problematic Internet use for Chinese college students. Cyberpsychology $\mathbb{E}$ Behavior, 10(6), 805-812.

Mittal, V. A., Tessner, K. D., \& Walker, E. F. (2007). Elevated social internet use and schizotypal personality disorder in adolescents. Schizophrenia Research, 94(1-3), 50-57.

Morahan-Martin, J., \& Schumacher, P. (2000). Incidence and correlates of pathological internet use among college students. Computers in Human Behavior, 16(1), 13-29.

Muñoz-Rivas, M. J., Fernández, L., \& Gámez-Guadix, M. (2010). Analysis of the indicators of pathological internet use in Spanish university students. The Spanish Journal of Psychology, 13(2), 697-707.
Orman, M. C. (1996). Internet Stress Survey. Retrieved from: http://www.stresscure.com/hrn/addiction. html

Sánchez-Carbonell, X., Berauny, M., Catellana, M., \& Oberst, U. (2008). La adicción a Internet y al móvil: imoda o trastorno? Adicciones, 20 (2), 149-160.

Widyanto, L., \& McMurran, M. (2004). The psychometric properties or the internet addicion test. CyberPsychology E Behavior, 7(4), 443-450.

Young, K. (1998). Internet addiction: The emergence of a new clinical disorder. CyberPsychology $\mathcal{E}$ Behaviour, 1(3), 237-244.

\section{Appendix I}

\section{Survey Structure}

V2. Age

V3. Sex

V4. Habitual place of residence: capital; province; other towns in Andalusia; other.

V5. Number of people with whom you share your habitual residence: 2 or less; $3-5 ; 6-8 ; 9-11 ; 12$ or more.

V6 to V12. Please specify which electronic equipment you habitually use (at least three times a week or for more than 10 hours a week): PC (computer); Laptop; Netbook (mini laptop); iPad or tablet; Smartphone; Other.

V13 to V21. Orman's Survey.

V22 to V41. Young's Test.

V42. How many hours do you spend online per day for reasons other than work or study?: None; Less than 2 hours; Between 2 and 5 hours; More than 5 hours.

V43. Where do you normally connect to Internet from? * You can choose several options: Work; Faculty; Home; Internet Café; Public places (parks, shopping centres, etc.); Other.

V44. Who pays for your Internet use? * You can choose several options: Me; My parents or relatives; My partner; My company, centre or university; Other.

V45. Do you think that your use of Internet interferes in your everyday life?: Yes; No.

V46. Has anyone close to you told you that you have a problem with technology because you appear not to be able to live without it?: Yes; No. 
